Etnográfica

Revista do Centro em Rede de Investigação em

Antropologia

vol. $16(3) \mid 2012$

Vol. $16(3)$

\title{
Built heritage-making and socioeconomic renewal in declining rural areas: evidence from Portugal
}

Construção de património edificado e revitalização socioeconómica em zonas rurais em declínio: evidência a partir de Portugal

\section{Luís Silva}

\section{(2) OpenEdition}

\section{Journals}

Electronic version

URL: https://journals.openedition.org/etnografica/2091

DOI: 10.4000/etnografica.2091

ISSN: 2182-2891

\section{Publisher}

Centro em Rede de Investigação em Antropologia

\section{Printed version}

Date of publication: 1 October 2012

Number of pages: 487-510

ISSN: 0873-6561

\section{Electronic reference}

Luís Silva, "Built heritage-making and socioeconomic renewal in declining rural areas: evidence from Portugal", Etnográfica [Online], vol. 16 (3) | 2012, Online since 08 October 2012, connection on 11 February 2022. URL: http://journals.openedition.org/etnografica/2091 ; DOI: https://doi.org/10.4000/ etnografica.2091

\section{(c) (7) (8)}

Etnográfica is licensed under a Creative Commons Attribution-NonCommercial 4.0 International License. 


\section{Built heritage-making and socioeconomic renewal in declining rural areas: evidence from Portugal}

\section{Luís Silva}

This article focuses on the connections between built heritage-making and socioeconomic renewal in declining rural areas. Drawing on fieldwork in twelve rural villages in eastern Portugal, it sheds light on the outcomes of a State-led programme, the objectives of which were to renovate the historic built fabric and generate tourism revenue for a region with declining population levels. Overall, the programme was successful in terms of preservation/conservation of monuments and the built fabric, but failed to stimulate the anticipated social and economic development. The conclusion is that the making of heritage spaces is not the remedy for the economic and demographic ills of rural areas, notwithstanding the positive effect that such measures may have in certain cases.

KEYWORDS: built heritage, rural heritage tourism, local impact, rural development, public investment, Historic Villages of Portugal.

Construção de património edificado e revitalização socioeconómica em zonas rurais em declínio: evidência a partir de Portugal - Este artigo analisa as conexões entre construção de património edificado e regeneração de estruturas socioeconómicas em zonas rurais. Com base em dados compilados em trabalho de campo efetuado nas Aldeias Históricas de Portugal, o artigo empresta visibilidade aos resultados de um programa promovido pelo Estado, cujos objetivos eram renovar os edifícios históricos e os tecidos construídos e desenvolver o turismo numa região em declínio populacional. Globalmente, o programa teve sucesso em termos da conservação/preservação dos monumentos e dos espaços edificados, mas não conseguiu estimular o esperado desenvolvimento social e económico. Conclui-se que a construção de espaços patrimoniais não é o remédio para os problemas económicos e demográficos das zonas rurais, apesar dos efeitos positivos que pode ter em certos casos.

PALAVRAS-CHAVE: património edificado, turismo rural, impacte local, desenvolvimento rural, investimento público, Aldeias Históricas de Portugal.

SILVA, Luís (luis.silva98@gmail.com) - Centro em Rede de Investigação em Antropologia, Faculdade de Ciências Sociais e Humanas da Universidade Nova de Lisboa, Portugal. 


\section{THIS ARTICLE PROVIDES AN ANALYSIS OF THE CONTEMPORARY} manufacture of built heritage. The main aim is to discuss the connections between built heritage-making and socioeconomic renewal in declining rural areas, particularly in developed countries. What are the effects of the heritage enterprise on the social context? To what extent does it promote economic diversification and growth? Does it alter demographic trends? Pursuing these questions in rural Portugal, the article examines how heritage measures and economic well being actually dovetail (or not) on the ground. In the process, it provides information that can be used to review rural development measures and policies. ${ }^{1}$

The discussion is centred on the case of the Historic Villages of Portugal. This is the name of a programme and network including twelve villages located in the central region of the country, near to the border with Spain, namely Almeida, Belmonte, Castelo Mendo, Castelo Novo, Castelo Rodrigo, Idanha-aVelha, Linhares da Beira, Marialva, Monsanto, Piódão, Sortelha and Trancoso. Ideas of historic conservation emerged in most of these villages in the first quarter of the twentieth century; at that time, castles, fortresses walls and pillories were accorded official protection status as "national monuments". Over time, other buildings became officially protected. In 1978, the built fabrics of Castelo Mendo and Piódão were classified as "buildings of public interest" and given protection status as such. ${ }^{2}$ More recently, in 1995, historic conservation was extended to the entire old village centres, in the framework of a State-led programme, entitled Recovery Programme for the Historic Villages of Portugal. This programme pursued two main goals: to renovate the historic buildings and the built fabrics (in sum: built heritage) and to generate tourism revenue for the village populations.

The core aim of this article is to provide an ethnographic contribution for the study of the outcomes of this programme at the local and, therefore, microlevel. To do that, I shall study the local impact of the programme, particularly in physical, social and economic terms. Special attention is paid to tourism. Of course, there are other agents of change in the villages aside from the programme and tourism. However, it is possible to isolate some direct and indirect types of impact resulting from these two factors (Mathieson and Wall 1982; Santana 1997). Although this requires the artificial segmentation of levels of

1 The study was made possible by a Fundação para a Ciência e a Tecnologia (Portuguese Foundation for Science and Technology) research grant (SFRH/BPD/34229/2006). I thank this institution for its support. I also thank the two anonymous Etnográfica reviewers for the comments on a previous version of this article. Special thanks go out to the inhabitants and to all other informants for their contribution to this study.

2 An artefact is considered to be of "public interest" when its protection and enhancement represents a cultural value of national importance, but for which the system of protection for "national monuments" is considered excessive. 
analysis that are merged in social reality (Mathieson and Wall 1982: 3), it is this line of enquiry that is pursued here.

The study is grounded on fieldwork - conducted in 2008 and 2009 - comprising two data collection strategies and two levels of observation. On the one hand, there was an extensive research across the villages, municipalities and institutions involved in the programme at all administrative levels, including interviews with the architects that designed the village plans. On the other hand, there was an intensive research during four months in each of the following villages: Belmonte, Castelo Rodrigo and Sortelha.

These villages were selected for three main reasons. First, they form part of the group of localities with a more developed tourism sector, in terms of supply and demand. Second, they have different sizes and administrative status Castelo Rodrigo and Sortelha are villages with less than 250 residents, whereas Belmonte is a small town with around 3,000 residents. Finally, they joined the programme at different stages, 1995 and 2003. Ethnographic observation, conversations and semi-structured interviews with residents, tourist entrepreneurs and tourists were the principal instruments for collecting data. As the research was a survey limited in time and rather large in scope, this work is but a point of departure in the study of its object.

\section{CONTEXT(S) AND BACKGROUND}

The Historic Villages of Portugal are in various ways an instance of the socioeconomic change that rural areas of Portugal have been undergoing in the last sixty years. Until the mid-twentieth century, the main occupation here was agriculture. Subsequently, the decline of agriculture triggered rural outmigration. Population censuses show that the number of residents increased between mid-nineteenth and mid-twentieth century, decreasing thereafter. In 2011 , the lowest number of inhabitants since mid-nineteenth century was recorded in most villages, and the majority had less than 200 inhabitants, most of which are elderly and have low levels of education and training.

Measures to combat the decline in economic activity began to be taken in the last quarter of the twentieth century. Some independent individuals, local and municipal governments, and the National Institute for the Advantageous Use of Workers' Free Time (INATEL) started to earn money by receiving a growing number of tourists in search of cultural tourism experiences. The first villages to have touristic facilities were Almeida and Sortelha. In Almeida, the first such facility, accommodation in the form of a Pousada de Portugal, appeared in 1985 as a State-driven initiative. ${ }^{3}$

3 In February 2010, it was excluded from that network, presently managed by a private group, having become a four-star hotel. 
In Sortelha, the first tourism business was set up by an aristocratic couple from greater Lisbon, who owned vast estates and a manor house in the village. They started the business in partnership with a small group of lawyers, doctors and engineers also from greater Lisbon, with whom in the previous decade they had discovered and appropriated the place as something of a romantic adventure. In the early 1970s, they began to explore a "traditional" restaurant in the old village centre. In both villages, much like in other Historic Villages of Portugal, the early initiatives were followed by subsequent ones, both public and private, aimed at making a business out of tourism.

The major initiative forms part of the object under study here. Designed by the national government and the Commission for the Development and Coordination of the Central Region, which coordinated it, the Recovery Programme for the Historic Villages of Portugal was implemented - with European Union funding - between 1995 and 2006, in cooperation with the Portuguese historic conservation agencies (the former IPPAR and the former DGEMN) ${ }^{4}$ the INATEL, municipalities and private agents. The village populations did not participate in the decision-making processes, but only in a sub-programme related to the renovation of private buildings. The inhabitants remember that "when we were called to talk to those responsible for the programme, everything was already decided".

Architects designed the village plans included in the application to the programme organized by the municipalities. These plans established the work to be done in the villages and the responsible entities (PPDR 1995). The municipalities proceeded differently at this point. While some commissioned independent and prominent architects to design the village plan, others resorted to their own staff.

Implementation began in 1995 in ten villages, but by 2003 it had spread to two others: Belmonte and Trancoso. Actually, the latter are not villages but small towns, with a few thousand inhabitants each. The selection of the first ten villages was justified by various criteria, such as the "existence of protected heritage", the "formal unity of the built fabric", the "desertification rate" and the "lack of tourism infrastructures" (Programa de Recuperação... 1994: 5). According to information gathered during an interview with the programme coordinator at her office in the city of Coimbra, an extension was already decided as part of a funding agreement between the national government and the European Union; however, because of economic constraints, the programme was extended to 12 villages instead of the 15 initially planned. She selected Belmonte and Trancoso for two main reasons: for possessing historic

4 IPPAR (Portuguese Institute for Architectural Heritage) and DGEMN (General Directorate for National Buildings and Monuments). These agencies disappeared in 2007, as a result of the creation of the Portuguese Institute for the Management of Architectonic and Archaeological Heritage (IGESPAR). 
and architectural values parallel to those of the first ten villages; and for having more services available and requiring less investment in basic infrastructure and tourism facilities than other candidates. ${ }^{5}$

The programme is part of rural development policies that have been promoting rural tourism in western European and other developed countries since the late twentieth century (for example, Jenkins, Hall and Troughton 1998; OECD 1994). As mentioned above, it sought to renovate built heritage and use it as lever of socioeconomic renewal through cultural tourism. In the words of the programme coordinator,

"The Historic Villages are collections of historic buildings and localities which have a major impact on our collective memory and which at a given moment we sought to renovate, in order to create tourist and cultural centres which might boost local development in a forgotten portion of our country".

The concept of heritage adopted is broad in scope, and includes military, religious and folk architecture, such as castles, churches, houses and barns (see Boura 2002; Programa de Recuperação... 1994). To better understand the situation, it is convenient to look back in time and move away from the Historic Villages of Portugal.

Interest in historic buildings and rural architecture emerged in the late nineteenth century, in a context marked by the emergence of national identity-building processes (Lowenthal 1998; Samuel 1994). As many authors (Leal 2000; Neto 2002; Prista 2011 ; Sobral 2004; Tomé 2002) point out, in Portugal, as in other European countries, historic monuments and forms of rural architecture were converted into emblems of national identity, especially during the dictatorship period (1927-1974). The case of the Most Portuguese Village competition launched by the regime in 1938 - in which housing was one of the main evaluation criteria - is a particularly striking example.

There has been renewed interest in historic and rural architecture during the last thirty years, but in a rather different context. The main aim is not to foster national identity, although this is not totally absent, but to generate tourism revenue for the village populations. The idea of income generation through the renovation of the historic built fabric is not by any means a new phenomenon in Portugal. In mid-twentieth century, Salazar's regime has restored the built fabrics of Óbidos and border villages such as Monção, Almeida, Monsaraz and Marvão also to promote (a then incipient) tourism (Prista 2011; Silva 2007;

5 The other candidates were the villages of Santar (Nelas), Algodres (Fornos de Algodres) and the aggregate of Alfaiates and Vilar Maior (Sabugal). The chairmen of the municipalities of Fornos de Algodres and Sabugal were outraged at the choice, as reported in the regional newspaper $O$ Interior in its edition of June 22, 2003. 
Tomé 2002). Nevertheless, there was a reversal of priorities, for tourism is now the main goal. In this line of reasoning, some authors (Alsayyad 2001; Rowan and Baram 2004) argue that there has been a shift from heritage constructed for the purposes of national identity-building to heritage constructed for tourist consumption and economic profit. In Portugal, this is evident in State-led programmes that renovate buildings and built fabric for tourism in rural areas, such as the Villages of Saudade in Minho, the Villages of Shale in the central region, the Water Villages in Alentejo, and the Historic Villages of Portugal, which are the object under study here.

Kirshenblatt-Gimblett's (1998) theorisation of heritage helps to better understand the situation. For the author, heritage practices endow objects, buildings, sites, technologies, or ways of life with a "second life as heritage", a life as "representations of themselves". Having exhausted the original functions, their first life, they are reborn as representations of what they once were. What is more, their "rebirth" is linked to tourism, for tourism makes economically viable heritage buildings, technologies, or practices that "can no longer sustain themselves as they formerly did" (1998: 149-151).

Elsewhere (Silva 2011), while examining precisely one Historic Village of Portugal, I have argued that the two lives of buildings or practices converted into heritage do not always follow a sequence in time as this theoretical formulation indicates, for in Castelo Rodrigo the houses have both, and simultaneously, a first life as social habitats for the village population and a second life as heritage; besides, the co-occurrence of first and second lives in the same buildings may become a bone of contention, as that second life tends to suffocate the first one. This article aims to expand the understanding of the local impact of the heritage enterprise, a topic that has received little attention in heritage studies.

\section{SETTING THE SCENE}

Most of the 44 million Euros that the programme invested in the villages was spent in rendering them "historic". The work started on historic monuments, such as castles, fortresses walls and churches. As noted elsewhere (Silva 2009a: 79-81), interventions on monuments followed different methodologies, preservation- or conservation-oriented, according to current architectural knowledge and international conventions and recommendations on the subject. Some monuments were adapted to new functions, particularly as museums and tourist offices (see figure 1; see also Atelier 15 2002, for details on the work done in Idanha-a-Velha).

Later on, the programme invested in the extensive renovation of façades and roofs of buildings located within the historic areas, especially houses and barns, except in Belmonte and Trancoso. While a few buildings could be 
described as upper-class villas, most of them are representative of lower-class folk architecture (see figure 2). The aims were to restore the façades and roofs of buildings, and to eliminate the modern and spurious industrial materials, such as brick, concrete and aluminium, which are considered to contaminate the prestigious materials of the past, such as stone and wood. Work began on buildings located in the main streets, regardless of their uses and functions. It was carried out in stages and funds came to an end before the renovation of all the buildings had been completed. Consequently, work was done on empty buildings, but not on all inhabited ones.

The arrangement of tourist spaces also involved basic infrastructure, the pavement of streets, renovation of public spaces and general embellishment. Electrical and communication cables were placed underground, especially to hide modernity from sight in a space that is being rendered "historic". New public lighting and urban furniture, such as benches and litter bins, were also placed in the villages. Moreover, markers were put at the entrance to and inside the villages, placing them "out of real time and space" (MacCannell 1999 [1976]: 41) and guiding tourists to what is distinctive and worth viewing (see figures 3 and 4).

As is often the case in tourist settings (Mathieson and Wall 1982), the renovation of the built fabric improved the quality of life of residents as to infrastructure, and exerted the psychological effect of enhancing their pride in the village, which they overall regard as "clean, pretty and restored". However, it did not improve significantly the living conditions of most residents, particularly the poorest among them, for various reasons.

First, as mentioned above, there are inhabited houses that did not undergo any intervention. In this respect, many residents, particularly less well-off people, complain that "the programme has rehabilitated the houses of the rich and not the houses of the poorest". Here, for example, is the statement of a lady in her forties living in Monsanto:

"The image of the village improved, because they renovated the roofs and façades of buildings, many of which were already in ruins. The problem was the criterion on which they based their work. They should have renovated the homes of permanent residents first, and especially the poorest among them, and the others afterwards. But this was not how they decided to do it. They renovated the houses of rich people and even old barns, and did not renovate the houses of some poor people".

Second, the work was poorly done in most cases, because the new roof tiles fall and break easily leading to water leaks, while the new wooden outwardfacing doors and windows do not provide proper insulation. In the words of one inhabitant in his late sixties in Castelo Rodrigo, 
"The village is fine for tourists but bad for those who live here, because the roofs of our houses collapse and cause water leaks. Besides, it is cold inside the houses, because the doors and windows that face outwards get warped and stop providing proper insulation, so that the houses become very damp. The old stone houses are damp by their very nature, you know?"

Likewise, the regional director of the former DGEMN said in interview that,

"Overall, the roofs of houses in all Historic Villages let in a lot of water. There are glaring situations. I have watched people crying, old people who have put plastic all around the inside of the house, because it rains everywhere due to faults in the building work, and lack of technical control of the project and the work".

Finally, the programme did not fund indoor improvements or the knocking together of properties with a view to expanding their available interior space. Apart from being small, the internal design of most houses does not conform to the physical and social requirements of a modern family, such as plenty of light, individual bedrooms and large bathroom spaces. The programme carried out indoor building work only to demolish or to create tourism-related businesses.

This is a major gap of the programme for most residents and architects, including those working for historic conservation agencies. In this respect, a lady in her fifties said in a conversation at her café in Marialva that "the programme should provide funds to renovate the inside of the houses, because the houses are old and require renovation. I have done this at my own expense, but most residents cannot afford to do this, because they are poor". Likewise, the regional director of the former DGMEN said during an interview at his office in the city of Oporto that,

"From the perspective of heritage, the programme was very positive, because there were funds available for work on the stock of historic buildings, and there was restoration, conservation and renovation of the historic and vernacular heritage. However, from the social point of view, there were gaps. The programme should have extended to the insides of the houses. [...] In some villages, there are families with cable television and electricity passing in front of the house, yet they do not have an indoor bathroom".

\section{THE VICISSITUDES OF TOURISM REVENUE}

In pursuing the purpose of economic diversification, the programme funded the creation of tourist facilities in most villages. In some cases, they are Stateowned. This includes eight tourist offices, four museums and two small hotels. 
In other cases, however, they are private - the programme funded projects that required a maximum of 100,000 Euros. Most of these provide tourist accommodation, particularly those included in Tourism in the Rural Space (TER in Portuguese) which the programme funded on 20 occasions. ${ }^{6}$ Table 1 provides a quantitative summary of tourist facilities in the Historic Villages of Portugal in 2009, few of which were created before the mid-1990s. It shows that the supply of facilities is not uniform across all villages.

Excepting Castelo Mendo, all the villages have a tourist office, which is normally run by the municipal government. Half of the villages also have museums, generally managed by the municipal governments as well. It is in Belmonte that the number of museums is higher (six).

Table 1

Tourist establishments in the Historic Villages of Portugal in 2009

\begin{tabular}{|c|c|c|c|c|c|c|c|c|}
\hline \multirow[t]{2}{*}{ Village } & \multicolumn{2}{|c|}{ 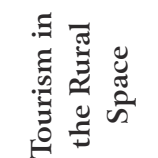 } & \multicolumn{2}{|c|}{ 预 } & \multirow{2}{*}{ 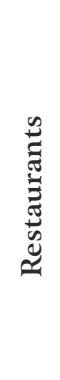 } & \multirow{2}{*}{ 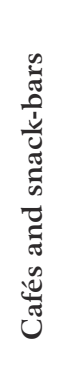 } & \multirow{2}{*}{$\begin{array}{l}0 \\
\frac{0}{0} \\
\frac{0}{\omega} \\
\frac{\pi}{0} \\
0 \\
0\end{array}$} & \multirow{2}{*}{ 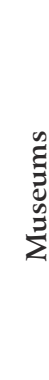 } \\
\hline & 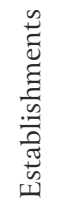 & $\underset{D}{\tilde{D}}$ & 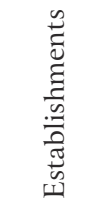 & $\underset{D}{\tilde{D}}$ & & & & \\
\hline Almeida & 2 & 6 & 3 & 69 & 4 & 6 & 1 & 1 \\
\hline Belmonte & - & - & $1+2^{*}$ & 80 & 8 & 17 & 1 & 6 \\
\hline Castelo Mendo & 1 & 1 & - & - & - & - & 1 & 1 \\
\hline Castelo Novo & 4 & 24 & 一 & - & 2 & 2 & 2 & 1 \\
\hline Castelo Rodrigo & 2 & 10 & $2^{*}$ & 14 & $1^{*}$ & 2 & 2 & - \\
\hline Idanha-a-Velha & - & - & - & - & - & 1 & - & 2 \\
\hline Linhares & l & 4 & l & 29 & 2 & 2 & 1 & - \\
\hline Marialva & 3 & 27 & - & - & l & 2 & l & - \\
\hline Monsanto & 2 & 7 & 1 & 10 & 2 & 1 & 5 & - \\
\hline Piódão & 3 & 11 & $1^{*}$ & 31 & 2 & 2 & 2 & 1 \\
\hline Sortelha & 7 & 21 & - & - & 2 & 3 & 1 & - \\
\hline Trancoso & l & 5 & 2 & 75 & 9 & 12 & 3 & - \\
\hline
\end{tabular}

* Establishment(s) located outside the village

6 Tourism in the Rural Space is a type of small scale and familial tourist accommodation that includes agro-tourism. 
Furthermore, all the villages provide tourist accommodation, excepting Idanha-a-Velha. Most of the establishments correspond to Tourism in the Rural Space, which are more numerous in Marialva - one business in Marialva includes eight houses - and Sortelha. The respective number of beds is low, ranging from one to six beds. The same can be said of occupancy rates, although exact figures on the number of tourists staying in local accommodation are unavailable for the localities under study. ${ }^{7}$ There are also small hotels in Almeida, Belmonte, Linhares da Beira, Piódão and Monsanto. In these cases, the number of beds ranges between 10 and 31 . Moreover, there are inns (pensões) in Almeida and Trancoso, where there is also a four-star hotel. These units offer between 21 and 53 beds. Usually, the establishments do not provide services other than accommodation and breakfast.

With the exceptions of Castelo Mendo and Idanha-a-Velha, the villages also have restaurants and local shops selling crafts, antiques and local/regional products. Normally, these businesses are in the private sector. However, in Castelo Rodrigo the local government owns a restaurant and a campsite with three bungalows, while the municipal government owns a regional products shop. Finally, all the villages have cafés or snack-bars.

The tourism entrepreneurs are not a homogeneous group; for example, there are some recent immigrants, of predominantly urban origin, and native couples. But it is possible to sketch a dominant profile. The respective characteristics may be summed up as follows: men or women; aged between 50 and 65 years old; good levels of education; considerable socioeconomic status; natives with experiences of living elsewhere in the country or abroad; low training in tourism and marketing; and for whom the investment is a family project. This includes chairmen and former chairmen of local governments, provincial elites, retired teachers, officials and engineers, and business people.

The investment required to create a tourism business is usually high, because of the costs of converting buildings previously associated with housing and agriculture. The investment increases when it is necessary to buy a building in a speculative market. Few of the permanent residents can therefore afford to set up tourism-related businesses. Most residents are elderly and have little economic and social capital to invest in tourism and to apply for funds offered by the State and the European Union. ${ }^{8}$ Hence, the village populations have unequal opportunities of accessing the economic tourism model, or of taking advantage of the "value of exhibition" (Kirshenblatt-Gimblett 1998:

7 At the national level, between 1986 and 2007, the occupancy rates in these units tended to be lower than 19 percent (Silva 2009b: 112, 2010: 45).

8 For example, a woman in her sixties in Monsanto confided that she would like having rooms in her house to accommodate tourists, but the small pension that she receives from the State does not allow her to create a space that meets the requirements set by the national agency for tourism (Turismo de Portugal). 
151-152). The situation parallels that studied by other authors in other touristic spaces in Portugal (Cavaco 1995a, 1999; Mendonsa 1983; Ribeiro and Marques 2002) and abroad (Herzfeld 1991; M. Smith 1989; Manwa 2003; Sparrer 2005).

Still, the growth of private and public tourism-related businesses and services led to the creation of some direct and indirect jobs, except in Castelo Mendo. In the other villages, the situation is as follows: less than 10 jobs were created in Castelo Novo, Castelo Rodrigo and Idanha-a-Velha; between 10 and 15 in Linhares da Beira, Marialva, Monsanto and Sortelha; around 20 in Piódão; and between 25 and 50 in Almeida, Belmonte and Trancoso. These jobs are undoubtedly significant for the local labour markets, since there are few jobs in other economic activities. But their relevance should not be overestimated. In two of the most successful cases, tourism occupies 17 percent of the active workers living in Castelo Rodrigo and 14 percent of those living in Sortelha, plus six non-residents in Castelo Rodrigo and two in Sortelha. Women account for an important share here, as is often the case in rural tourism (Bouquet and Winter 1987; Cánoves et al. 2004; Lane 1994, 2009).

The main reasons for the low impact of tourism on employment are the small scale and family-based nature of most businesses operating in rural tourism. Because of their family dynamics, most businesses take on only one or two employees, usually part-timers, as is usual in tourism (Mathieson and Wall 1982; Santana 1997). The exception to this trend are larger establishments with greater capacity, such as hostels, hotels and a project that includes a restaurant and eight small tourist facilities in Marialva. These projects employ an average of six or seven full-time employees, and three or four part-timers, in the reception of guests, cleaning, cooking, serving meals, and attending the bar. The smaller establishments tend to employ women born and living in the villages, while the larger ones also include individuals from other nearby villages and regions.

The tourism services in the public sector are not different in this regard. For example, the tourist offices employ between one and four full-time workers, mostly female. These jobs require higher qualifications, such as secondary school and university, than those needed for hotel and restaurant work. Knowledge of foreign languages does not seem to be a priority, since most employees lack it. Training in tourism is often obtained in activities organized by the municipal or local governments, such as an event held in Castelo Rodrigo in 2002-2003, entitled Castelo Rodrigo Evenings. ${ }^{9}$ In some villages the positions in tourist offices are occupied by residents, while in others the employees are non-residents. This is also the case of museums and other heritage spaces. 
In some cases, these are normally closed to the public and do not provide any jobs, as occurs in Castelo Mendo, but most museums have one full-time employee, usually female.

The programme had a significant impact on architectural knowledge and the construction sector, as is often the case in historic conservation (Herzfeld 1991). Unfortunately, an opportunity to increase architectural knowledge of historic domestic architecture was missed. As the regional director of the former IPPAR said during an interview at his office in the city of Castelo Branco,

"In the first phase, before the creation of the regional directorate of the IPPAR of Castelo Branco, the programme failed in architectural terms. This region is very rich in terms of sixteenth-century architecture. Not enough care was taken in dealing with this. Most of these houses were completely demolished on the inside, and valuable information on the history and development of habitation in Portugal was thus lost forever. [...] In all the villages. As a rule, the interiors of the houses were completely destroyed, while roofs and façades were rebuilt".

But the leader of the team of architects from Oporto who designed the village plan for Idanha-a-Velha began to use it as a case study in the courses taught at the faculty of architecture (Atelier 15 2002). Moreover, the leader of the other team of architects from Oporto which designed the village plan for Castelo Rodrigo won an award at the Milan Architecture Biennale for the "memorial of the ruins" of the palace of Cristóvão de Moura.

The programme had also a significant impact on the construction sector. As the regional director of the former DGEMN pointed out, "the work on heritage has become a business for designers and contractors". Furthermore, in almost all the villages building work has not ceased since the mid-1990s. Within the programme, the municipalities launched public or restricted requests for tenders, depending on the value of the envisioned contract: above or below 100,000 Euros. In most cases, those contracts were awarded to nonlocal specialised companies, which sometimes recruited permanent residents. Although the programme has ended, it is common to see a roof being mended or a house being renovated. The works are normally carried out by masons, carpenters and builders who live in the villages or nearby. ${ }^{10}$

In Belmonte, Castelo Rodrigo, Idanha-a-Velha, Monsanto, Sortelha and Piódão tourism is also a source of additional household income for a fairly small number of residents, through the manufacture and sale of crafts and homemade food products. Examples are the employee of a wool cooperative in

10 Municipal and local governments also recruit workers to clean and maintain public spaces, usually two individuals. 
Belmonte and six women in Sortelha, as well as three elderly women in Monsanto and a retired couple in Idanha-a-Velha. Some snack-bar owners in Castelo Rodrigo and Sortelha also fall into this category. ${ }^{11}$

The tourism sector occupies (directly and indirectly) an average of 11 percent of village populations; the standard deviation is \pm 9.63 . Pluriactivity is the order of the day for the residents, and the individuals involved in tourism have multiple jobs and sources of income, such as farming, jobs in construction and other economic activities. This is the case, for example, of a couple in their fifties in Sortelha. The couple explores a tourist accommodation and a shop selling crafts and antiques, being simultaneously engaged in the macro generation of wind energy, in local government and in farming practices for family consumption. ${ }^{12}$ Largely, this is linked to the seasonal nature of tourism. Private tourism businesses tend to operate only at weekends, during school holidays and in festive seasons, due to low demand at other times, as is usual in tourist destinations (Mathieson and Wall 1982; Santana 1997).

Since 2005, local tourist offices have recorded almost continuous growth in the number of annual tourists, which nevertheless remains modest. In 2009, Almeida and Sortelha had about 60,000 tourists each; Castelo Rodrigo about 47,000; Castelo Novo and Monsanto more than 20,000 each; and the other villages around 12,000 each. Most tourists are Portuguese, and Spaniards predominate among foreigners because of geographical proximity. Tourist flows are not constant and range from low daily demand to occasional high demand. During the week the number of tourists tends to be low. At weekends the number of tourists reaches a few hundred. It is in the festive season (Carnival, Easter and New Year) and in the summer, particularly in August, that the demand is most intense. Many (but not most) tourists visit different villages in the network, but most tourists do not eat or stay overnight, although exact figures on the number of meals served at local restaurants are also unavailable for the Historic Villages of Portugal.

Locally, the economic impact of tourists' visits is of the modest kind that we find in many rural villages of Europe, although providing income to a small number of residents. "Evidence suggests that 10-15 percent of tourists' expenditures remain as benefits to local people" (Nuryanti 1996: 256; see also Cavaco 1995b; Hodges 2009; Silva 2007, 2009b; Timothy and Boyd 2003). For the initiators of the programme (and other agents), this represents failure, in that the development of "quality tourism" - an euphemism for affluence and purchasing power at the destination - was the ultimate goal.

11 Here, there are a few residents who sometimes sell dried figs and cherries to tourists as well.

12 This is also the case of a lady in her thirties in Castelo Mendo. She explores a small tourist accommodation and a café in the village - with the help of her mother -, while simultaneously working at a service station nearby and being chairman of the local government. 
In 2006, at the instigation of the programme coordinator, the Association for the Development of Tourism in the Historic Villages of Portugal was created to change the situation. Of course, this is not an easy task, for tourism is a "demand driven activity that is difficult to control" (McKercher and Du Cros 2002: 30). The project related to Jewish heritage in the Historic Villages of Portugal that the association is currently working on is certainly valuable, as are the entertainment activities, such as historic re-enactments and fairs, created in most villages, which nevertheless remain scarce. However, more could be done to develop the marketing strategies necessary for success, although this has improved lately with the creation of the official website - http://www.aldeiashistoricasdeportugal.com/. It is also necessary to give rural entrepreneurs the required skills and resources for the effective marketing of their businesses, for which information and communication technologies are indispensable and co-operative marketing can be a good option (Embacher 1994; Herbert, Prentice and Thomas 1989; Nuryanti 1996; Sharpley and Sharpley 1997).

\section{SOCIAL EFFECTS: A BRIEF OVERVIEW}

In social terms, the programme facilitated the emergence of new agents and relations in the villages. There are, for example, institutional relations with other places, such as between local governments and the Commission for the Development and Coordination of the Central Region based in Coimbra, on the one hand, and the regional directorate of the IGESPAR based in Castelo Branco, on the other. Relations between tourism entrepreneurs and the Portuguese agency for tourism, as well as with the LEADER programme funded groups in the region have also emerged.

Plus, the residents have initiated a difficult relationship with the architects and historic conservation agencies due to dissonance regarding architecture and the aesthetic characteristics of houses. While historic conservation supposes an endeavour to freeze architecture in time, the residents wish to continue to transform their social habitats according to changing circumstances (Silva 2009a, 201 1).

The encounter between residents and tourists, both in establishments and in the street, has become frequent. Tourists are a heterogeneous group of "cultural tourists" (McKercher and Du Cros 2002: 3-8). Most of them are elderly tourists on a day trip who come in coach tours, but there are also groups of friends and families (with and without children) who visit the villages independently and come by car, including many city dwellers driven by a "pastoral ideal" (Marx 1967 [1964]). They usually come here on the recommendation of a family member or friend who has told them that "it is worth a visit", or by chance, or because they saw the place in a tourist guide. The main tourist 
attractions are the built fabrics comprising historic buildings and vernacular architecture. The touristic image of the villages - that the touristic experience usually reiterates, as many visitors stated during my fieldwork -, is that of "rustic" and "typical" "medieval villages".

The ideas of Urry (2002 [1990]) are appropriate for describing the tourist practices that prevail in the villages. The author argues that tourists see objects in a special way. The "tourist gaze" describes the visual consumption of signs or symbols considered as extraordinary from a culturally specific viewpoint and, therefore, worthy of viewing, and, simultaneously, the exclusion of what is not so regarded. Hence, "once people visit places outside capital cities and other major centres, what they find pleasurable are buildings which seem appropriate to a place and which mark that place off from others" (Urry 1999: 224).

This is what happens in the Historic Villages of Portugal. Most tourists walk more or less quickly through the villages, seeing, photographing or filming monuments and other buildings. They leave in search of new tourist spaces and experiences when, in their words, "everything has already been seen". However, they use other senses to experience and consume "local" and "traditional" products and flavours, and food tourism is important in villages such as Linhares da Beira, Piódão and Sortelha.

The residents do not rule out the presence of tourists; rather, they welcome them, for different reasons. One reason is that tourists provide, and are expected to provide, income to local people. The residents differentiate three types of tourists: those who stay in local accommodation and those who visit the village for the short gaze, among which the people in organized tours are differentiated from families on a journey. The differentiation is based primarily on purchasing power and local expenditure (Silva 2007).

Overall, tourist expenditures are regarded as seasonal and falling short of expectations and needs, though. Actually, most residents and tourism entrepreneurs perceive a gap between the (political) rhetoric of tourism as a powerful source of income growth and the practice of tourism as a seasonal activity providing low profitability, as is usual in rural Portugal (Ribeiro 2003; Ribeiro and Marques 2002). This is evident in the words of a resident in his seventies in Castelo Rodrigo:

"The initiators of the programme and the local mayors came here looking for oil, but we only have stones. They said that it would be the beginning of a new era for the village, an era in which tourism would generate meaningful income growth and job opportunities for the village population, but this never happened, except for the five ladies working at the tourist office". 
Another example is that of a 67-year-old retired French bank clerk who settled in Castelo Rodrigo to run a tourism business comprising a teahouse, a gourmet food store and a shop selling handicrafts: "I bought a number of ruined buildings and invested here, but I am losing money every day. I am away from my family in Lisbon, I have already had to lay off two employees, and I am thinking of closing the business next September".

Of course, the view is not shared by everyone, especially not by tourist entrepreneurs and local politicians, as shown by the following testimonies:

"My partner and I created a tour company two years ago, and set up the head office in Castelo Novo - one of the conditions for funding was that it be established in a Historic Village. So far, it has been a success. We are bringing in tourists from all over the world (Americans, Canadians, French and British) to walk and cycle in the region, in the Historic Villages" [Male, 30-35, tourist entrepreneur].

"Tourism is a great source of revenue for Sortelha. Directly or indirectly, most residents are now linked to tourism. Some sell figs and liqueurs, and others bracejo handicrafts, wooden handicrafts, embroideries and tapestries, or stone sculptures. Everyone has invented something, and everyone earns money. But it is clear: with the tourist trade we have to do much like the ant, working in the summer to live in the winter" [Male, 50-55, tourism entrepreneur and chairman of local government].

Another reason why residents welcome tourists is because there are situations in which they help to overcome solitude. Especially in the smaller villages, residents express satisfaction at having someone to see and with whom to exchange a few words. Here, for example, is the case of a lady in her late sixties living in Castelo Rodrigo: "Tourists are welcome here. They do not harm us; they provide earnings for some people, restaurants, and cafés; and it is fine to see someone with whom to exchange a few words, like you, for example".

What the residents do not like is to be looked upon as "animals in a zoo" by tourists who take pictures of them without asking permission and who invade the privacy of their houses by peering through the windows and entering if the doors are open. The museum of Piódão has a representation of a "traditional" house also to help prevent this. The encounter between residents and tourists, or hosts and guests (V. Smith 1978) is marked by ephemeral and instrumental relationships, occurring in the framework of information-gathering or in a commercial transaction, as is customary in tourist destinations (Nuñez 1978: 212).

Hotels and inns, Tourism in the Rural Space units, restaurants, cafeterias and shops selling local/regional products and artisanship are some of the new types of businesses that have emerged in most villages. In several villages, 
tourism affected interpersonal relations, either because of tensions and conflicts related to competition or because of cooperation and coalitions. ${ }^{13}$

The newer entrepreneurial activities also affected social structures, as in various villages some individuals attained higher social positions and reinforced their power relations as a result of starting tourism businesses. The most obvious case is that of tourist entrepreneurs who have become local chairmen, as occurred in three villages. In total, there are six chairmen of local government engaged in (family) tourism projects in the Historic Villages of Portugal.

In most villages, the programme attracted newcomers, of predominantly urban origin, looking for tourism businesses and, especially, second homes. Unfortunately, this influx came to hinder the social reproduction of the villages' populations because it has raised the price of buildings to the extent that local people can no longer afford to buy houses and the few newly married couples look elsewhere to buy their first home (Silva 2011: 49-50), as is often the case in popular rural areas (Sharpley and Sharpley 1997: 142; Woods 2005: 234-236). The most striking case is that of the walled village of Sortelha, which is permanently inhabited by only six people, and in the near future might turn out to be an "empty meeting ground" (MacCannell 1992).

Yet, there are cases of individuals and families, though not many, who remained and continue to live in the localities (or nearby) because of tourism. Here one witnesses a positive effect of the heritage enterprise: the mitigation of out-migration among rural dwellers, as occurred in Belmonte, Piódão and Sortelha. However, the number of permanent residents continues to decline in almost all villages due to continuity in out-migration and a negative population growth. The exception to this trend is Trancoso, but Trancoso was officially accorded the status of town in 2004 and, thus, benefits from urbanisation.

Overall, residents feel proud to live in a renovated historic village. They also acknowledge that the renovation of the built fabric has a positive effect on the development of tourism, and consider tourist expenditures to be important to the local people and economy. And yet, in all the villages, but particularly in the smaller ones, many residents feel that the circumstances of their lives and livelihoods have not improved in a meaningful way. Houses no longer provide appropriate living conditions as they once did, and they feel that they can no longer afford to improve them as before, because of restrictive disciplinary measures; there are few young people; unemployment affects a significant

13 For example, in Sortelha two sisters in their seventies stopped talking to each other because of a quarrel related to the business of bracejo handicrafts, while in Piódão there is conflict between sellers of handmade crafts and local/regional products, as well as between the owners of licensed tourist accommodation units and those providing unlicensed accommodation. Conversely, in most cases the owners of Tourism in the Rural Space units cooperate, albeit informally, with the owners of restaurants and snack-bars in the village and nearby. 
proportion of the population of working age; access to medical care is often lacking, because there are no health centres or pharmacies; children have to attend schools in other villages; public transport tends to be scarce; and tourism revenue is low. These are the main reasons why some residents even reply, "You say that because you do not live here", to tourists extolling the paradisiacal nature of their villages, as I heard from residents in their sixties in Belmonte, Castelo Rodrigo and Sortelha.

\section{CONCLUSION}

The aim of the article was to examine the connections between built heritagemaking and socioeconomic renewal in declining rural areas. In other words, it set out to provide an ethnographic case study of the local impact of the heritage enterprise. The contribution focuses on twelve Portuguese rural villages included in a State-led programme, the objectives of which were to renovate the historic buildings and the built fabric and to generate tourism revenue for a region with declining population levels.

In what regards the renovation of the built fabric, including historic monuments and rural architecture, research has shown that the programme was successful, overall. This is the major virtue of the programme for its initiators and architects. Most residents and tourists also appreciate the initiative, despite the criticism of residents regarding the works done in monuments and domestic architecture (Silva 2009a, 201 1). Apart from having better basic infrastructure, the villages have now a new image and urban furniture, and become more attractive for tourists and more pleasant for residents.

Unfortunately, the work did not improve in a meaningful way the living conditions of most residents, especially the poorest among them, because it focused on the façades and roofs of buildings; there are problems of insulation arising from this type of work, and the majority of houses are too small for a modern family and do not have sufficient light. This is a major gap of the programme for most residents and architects. In addition, many of the renovated buildings are not inhabited and their roofs already need repair. The question is: who is or will be in charge of the physical maintenance of buildings, in order to prevent them falling into disrepair?

In what regards the generation of economic well being, there is strong evidence that the positive outcomes of built heritage-making at the local and, thus, micro-level tend to be modest. Heritage tourism generates revenue for the village populations, but this has usually a feeble effect on the local economies, and benefits a small part of the residents, especially the better-off ones, as is often the case in rural tourism.

Moreover, tourism revenue is contextually dependent, being very low in Castelo Mendo and Idanha-a-Velha, and more meaningful in Belmonte, Castelo 
Rodrigo and Sortelha, mainly because of the number and type of establishments that have developed. The tourism projects tend to have the small scale and family-based nature characteristic of the rural tourism industry worldwide, being owned by the residents with higher social positions. The number of jobs created is low, as are the wages, as tends to occur in rural tourism (M. Smith 1989). In the process, tourism has become a complementary economic activity developed by an average of 11 percent of the villages' residents; the standard deviation is \pm 9.63 .

The factors that hamper the achievement of economic diversification and growth through heritage tourism are those characteristic of so many parts of rural Europe: significant investment required to create a tourism business; low return on investment; limited number of entrepreneurs; little training in tourism and marketing strategies of entrepreneurs; the small scale of the industry; and increased intra-rural competition (Cavaco 1995b; Gannon 1994; Hall, Roberts and Mitchell 2003; Lane 1994, 2009).

Therefore, efforts could be made to maximise the benefits of tourism, starting with effective marketing, the promotion of entrepreneurship and training of entrepreneurs in tourism and marketing strategies, for which information and communication technologies are indispensable and co-operative marketing can be a good option. Of course, one must bear in mind that there are a number of factors hindering socioeconomic development in the Historic Villages of Portugal, such as small and aging village populations, few residents capable to engage in economic initiatives and lack of public services, infrastructure and job opportunities.

New agents and social relations have emerged in the villages as a result of the heritage enterprise, including institutional relations with other places, development of new entrepreneurial activities and frequent encounters between residents and tourists. The newer entrepreneurial activities contributed to mitigate out-migration in some villages, but they have also affected social structure in some cases and altered interpersonal relations in many others.

In many cases, the project triggered the arrival of outsiders, of predominantly urban origin, looking for tourism businesses and, especially, second homes to the extent of hindering the social reproduction of the village populations as young couples move away to other areas due to high property prices. Yet (and as a result), the number of permanent residents continues to decline due to a negative population growth and continuity in rural out-migration. The encounter between residents and tourists occurs in different spaces, in establishments and on the streets, and is marked by ephemeral and instrumental relationships, as is often the case in tourism.

Arguably, more in-depth research is needed to better understand a certainly far more complex transition to an economic model based on a renovated past than was discussed here. Of course, the results will depend on the scale 
adopted, for the local impact of heritage-making is likely to differ from the regional impact. This article focuses on the local and, therefore, village-level. The social and economic effects of the initiative at the regional level have yet to be studied, though they are likely to be discreet.

Although it is impossible to generalize on the basis of the research results, at least not without a certain amount of caution, because the outcomes of historic built heritage-making are contextually dependent, or because of "the local specificity of a global heritage regime" (Bendix 2009: 255), this case study may help to improve rural development measures and policies. On the one hand, the social context cannot be sacrificed in favour of the historic/aesthetic context, and residents should take an active part in the decision-making processes, even though the low cultural and social capital of most residents is a major problem in this regard.

On the other hand, tourism can be an easy way to diversify the sources of income of rural dwellers in a number of cases, and also to mitigate outmigration, but tourism cannot solve the problems of rural areas, and is not an appropriate development tool for all of them (for example, Hall, Roberts and Mitchell 2003: 5; OECD 1994). Therefore, public authorities should promote further economic restructuring in rural areas if they want them to be lived in, and not just be used for tourism, as it is recommended when the rural economy is already weak (Butler and Clark 1992 cit. in Woods 2005: 69). Encouraging in-migration might be a good option as well, but public services and infrastructure are also required.

\section{REFERENCES}

ALSAYYAD, Nezar, 2001, "Global norms and urban forms in the age of tourism: manufacturing heritage, consuming tradition”, in Nezar Alsayyad (ed.), Consuming Tradition, Manufacturing Heritage: Global Norms and Urban Forms in the Age of Tourism. New York, Routledge, 1-33.

ATELIER 15, 2002, "Notas sobre a intervenção em Idanha-a-Velha", Estudos/Património, 2: 164-181.

BENDIX, Regina, 2009, "Heritage between economy and politics: an assessment from the perspective of cultural anthropology", in Laurajane Smith and Natsuko Akagawa (eds.), Intangible Heritage. Oxon and New York, Routledge, 253-269.

BOUQUET, Mary, and Michael WINTER (eds.), 1987, Who from Their Labours Rest? Conflict and Practice in Rural Tourism. London, Gower. 
BOURA, Isabel (ed.), 2002, Aldeias Históricas de Portugal: Um Património com Futuro. Coimbra, Comissão de Coordenação da Região Centro.

CÁNOVES, Gemma, et al., 2004, "Rural tourism in Spain: an analysis of recent evolution", Geoforum, 35 (6): 755-769.

CAVACO, Carminda, 1995a, "Rural tourism: the creation of new tourist spaces", in Armando Montanari and Allan Williams (eds.), European Tourism: Regions, Spaces and Restructuring. Chichester and New York, John Wiley and Sons, 127-149.

CAVACO, Carminda, 1995b, "Tourism in Portugal: diversity, diffusion, and regional and local development", Tijdschrift voor Economische en Sociale Geografie, 86 (1): 64-71.

CAVACO, Carminda, 1999, "O turismo rural nas políticas do turismo em Portugal", in Carminda Cavaco (ed.), Desenvolvimento Rural: Desafio e Utopia. Lisbon, Centro de Estudos Geográficos, Universidade de Lisboa, 281-292.

EMBACHER, Hans, 1994, "Marketing for agritourism in Austria: strategy and realisation in a highly developed tourist destination", Journal of Sustainable Tourism, 2 (1-2): 61-76.

GANNON, Agnes, 1994, "Rural tourism as a factor in rural community economic development for economies in transition”, Journal of Sustainable Tourism, 2 (1): 51-60.

HALL, Derek, Lesley ROBERTS, and Morag MITCHELL, 2003, “Tourism and the countryside: dynamic relationships", in Derek Hall, Lesley Roberts and Morag Mitchell (eds.), New Directions in Rural Tourism. Aldershot, Ashgate, 3-15.

HERBERT, David, Richard PRENTICE, and Colin THOMAS (eds.), 1989, Heritage Sites: Strategies for Marketing and Development. Aldershot, Avebury.

HERZFELD, Michael, 1991, A Place in History: Social and Monumental Time in a Cretan Town. Princeton, NJ, Princeton University Press.

HODGES, Matt, 2009, "Disciplining memory: heritage tourism and the temporalisation of the built environment in rural France", International Journal of Heritage Studies, 15 (1): 76-99.

JENKINS, John, Colin HALL, and Michael TROUGHTON, 1998, “The restructuring of rural economies: rural tourism and recreation as a government response", in Richard Butler, Colin Hall and John Jenkins (eds.), Tourism and Recreation in Rural Areas. Chichester, John Willey and Sons, 43-65.

KIRSHENBLATT-GIMBLETT, Barbara, 1998, Destination Culture: Tourism, Museums, and Heritage. Berkeley, Los Angeles and London, University of California Press.

LANE, Bernard, 1994, "Sustainable rural tourism strategies: a tool for development and conservation", Journal of Sustainable Tourism, 2 (1-2): 102-111.

LANE, Bernard, 2009, "Rural tourism: an overview", in Tazim Jamal and Mike Robinson (eds.), The SAGE Handbook of Tourism Studies. London, Sage Publications, 354-37 1.

LEAL, João, 2000, Etnografias Portuguesas (1870-1970): Cultura Popular e Identidade Nacional. Lisbon, Dom Quixote.

LOWEnTHAL, David, 1998, The Heritage Crusade and the Spoils of History. Cambridge, Cambridge University Press.

MacCANNELL, Dean, 1992, Empty Meeting Grounds: The Tourist. London, Routledge.

MacCANnell, Dean, 1999 [1976], The Tourist: A New Theory of Leisure Class. London, Macmillan.

MANWA, Haretsebe, 2003, "Wildlife-based tourism, ecology and sustainability: a tug-of-war among competing interests in Zimbabwe”, Journal of Tourism Studies, 14 (2): 45-55. 
MARX, Leo, 1967 [1964], The Machine in the Garden: Technology and the Pastoral Ideal in the America. Oxford, Oxford University Press.

MATHIESON, Alister, and Geoffrey WALL, 1982, Tourism: Economic, Physical and Social Impacts. New York, Longman Group Limited.

McKERCHER, Bob, and Hilary DU CROS, 2002, Cultural Tourism: The Partnership between Tourism and Cultural Heritage Management. New York, The Haworth Hospitality Press.

MENDONSA, Eugene, 1983, “Tourism and income strategies in Nazaré, Portugal”, Annals of Tourism Research, 10 (2): 213-238.

NETO, Maria, 2002, Memória, Propaganda e Poder: O Restauro dos Monumentos Nacionais (1929-1960). Oporto, Faculdade de Arquitectura da Universidade do Porto.

NUÑEZ, Theron, 1978, "Tourist studies in anthropological perspective", in Valene Smith (ed.), Hosts and Guests: The Anthropology of Tourism. Philadelphia, University of Pennsylvania Press, 207-216.

NURYANTI, Wiendu, 1996, "Heritage and postmodern tourism", Annals of Tourism Research, 23 (2): 249-260.

OECD, 1994, Tourism Strategies and Rural Development. Paris, Organisation for Economic Cooperation and Development.

PPDR, 1995, Intervenção Aldeias Históricas de Portugal, Beira Interior, Planos das Aldeias. Lisbon, Promoção do Potencial de Desenvolvimento Regional.

PRISTA, Marta, 2011 , Discursos sobre o Passado: Investimentos Patrimoniais nas Pousadas de Portugal. Lisbon, Faculdade de Ciências Sociais e Humanas, Universidade Nova de Lisboa, unpublished $\mathrm{PhD}$ dissertation in Anthropology.

Programa de Recuperação de Aldeias Históricas de Portugal: Acção Piloto de Promoção do Potencial de Desenvolvimento Regional, 1994, Lisbon, Ministério do Planeamento e Administração do Território, Ministério do Comércio e Turismo.

RIBEIRO, Manuela, 2003, "Pelo turismo é que vamos/poderemos ir (?): sobre as representações e as visões dos responsáveis das administrações públicas de âmbito local, acerca do turismo para o desenvolvimento local”, in Orlando Simões and Artur Cristovão (eds.), TERN: Turismo em Espaços Rurais e Naturais. Coimbra, Instituto Politécnico de Coimbra, 41-56.

RIBEIRO, Manuela, and Carlos MARQUES, 2002, "Rural tourism and the development of less favoured areas: between rhetoric and practice", International Journal of Tourism Research, 4 (3): 211 1-220.

ROWAN, Yorke, and Uzi BARAM, 2004, "Archaeology after nationalism: globalization and the consumption of the past", in Yorke Rowan and Uzi Baram (eds.), Marketing Heritage: Archaeology and the Consumption of the Past. Walnut Creek, CA, Altamira Press, 3-26.

SAMUEL, Raphael, 1994, Theatres of Memory, vol. 1: Past and Present in Contemporary Culture. London and New York, Verso.

SANTANA, Agustín, 1997, Antropología y Turismo: ¿Nuevas Hordas, Viejas Culturas? Barcelona, Ariel.

SHARPLEY, Richard, and Julia SHARPLEY, 1997, Rural Tourism: An Introduction. Oxford, International Thomson Business Press.

SILVA, Luís, 2007, "Sortelha e Monsaraz: estudo de caso de dois lugares turísticos no interior de Portugal”, Análise Social, XLII (184), 853-874.

SILVA, Luís, 2009a, "Heritage building in the 'Historic Villages of Portugal': social processes, practices and agents", Journal of Ethnology and Folkloristics, 3 (2): 75-91. 
SILVA, Luís, 2009b, Casas no Campo: Etnografia do Turismo Rural em Portugal. Lisbon, Imprensa de Ciências Sociais.

SILVA, Luís, 2010, "Perspectiva antropológica do turismo de habitação em Portugal", Pasos: Revista de Turismo y Patrimonio Cultural [online], 8 (1): 31-46, available at <http://www. pasosonline.org $>$ [access in 06/10/2011].

SILVA, Luís, 2011 , "Beneath the surface of the heritage enterprise: governmentality and cultural representation of rural architecture in Portugal", Ethnologia Europaea, 41 (2): 39-53.

SMITH, Michal, 1989, Behind the Glitter: The Impact of Tourism on Rural Women in the Southeast. Lexington, KY, Southeast Women"s Employment Coalition.

SMITH, Valene (ed.), 1978, Hosts and Guests: The Anthropology of Tourism. Philadelphia, University of Pennsylvania Press.

SOBRAL, José, 2004, "O genuíno, o espúrio e a identidade local: um estudo de caso das políticas de património em meio rural”, Etnográfica, 8 (2): 243-271.

SPARRER, Marion, 2005, Turismo no Espazo Rural e Desenvolvemento: Estudo Comparativo da Província da Caruña e o Landkreis Wittmund. Santiago de Compostela, Xunta de Galicia.

TIMOTHY, Dallen, and Stephen BOYD, 2003, Heritage Tourism. Harlow, Essex, Pearson Education Limited.

TOMÉ, Miguel, 2002, Património e Restauro em Portugal (1920-1995). Oporto, Faculdade de Arquitectura da Universidade do Porto.

URRY, John, 1999, “Gazing on History", in David Boswell and Jessica Evans (eds.), Representing the Nation: A Reader. Histories, Heritage and Museums. London and New York, Routledge, 208-232.

URRY, John, 2002 [1990], The Tourist Gaze: Leisure and Travel in Contemporary Society. London, Sage Publications, 2nd edition.

WOODS, Michael, 2005, Rural Geography: Processes, Responses and Experiences in Rural Restructuring. London, Thousand Oaks and New Delhi, Sage Publications. 